\title{
THE COMPETITIVENESS OF CHINA'S CHEMICAL SECTOR: ASSESSMENT AND IMPLICATIONS FOR EVSL, POLICY
}

\section{SUN XUEGONG}

The negotiation of the APEC early voluntary sectoral liberalisation (EVSL) policy has gone through a critical stage. Among the nine pilot sectors nominated by the APEC summit in Vancouver, the chemical sector is of most concern to policymakers in China and its major trading partners. This is not only because the chemical sector is the largest sector in terms of trade volume and output, but also because the chemical sector has a significant impact on other industrial sectors, and on people's lives. Subsequently, the question of the inclusion of China's chemical sector in early sectoral liberalisation is an important one for China, and will have long-term and strategic effects on the Chinese economy. This chapter examines the potential impact of the participation of China's chemical sector in APEC EVSL, and its policy implications. Because the international competitiveness of a sector is important in determining whether that sector will benefit from EVSL, a careful assessment of the international competitiveness of China's chemical sector is undertaken.

\section{THE INTERNATIONAL COMPETITIVENESS ASSESSMENT SCHEME}

There is no universally accepted definition for the international competitiveness of an industrial sector. In what follows, the international competitiveness of China's chemical sector is assessed in light of five aspects

- market performance

- product identification - price and quality

- productivity

- development capability - equipment and research and development (R\&D)

- industry environment-degree of concentration, upstream and downstream relations, market volume. 
The assessment scheme measures the competitiveness of China's chemical sector from different perspectives and at different levels. Some aspects reflect current competitiveness - for example, market performance-while others demonstrate long-term and potential competitive capablity. Some aspects can be observed directly in the market - such as price and market share-while others are more fundamental factors - for example, productivity.

\section{COMPETTTIVENESSASSESSMENTOF CHINA'S CHEMICALSECTOR}

\section{THE MARKET PERFORMANCE OF CHINA'S CHEMICAL, SECTOR}

The competitiveness of an industry is embodied in its ability to satisfy both the quantitative and qualitative needs of the market. In light of this, the trade competitiveness index (TC), revealed comparative advantage (RCA), and market share can be used to measure the current international competitiveness of an industry or product.

Based on the TC criteria, the chemical sector, in general, is still weak in terms of competitiveness. The TC for China's chemical sector has been negative since 1992. The trade deficit for the chemical sector also remains high, at US\$6.5 billion. The sector clearly still lacks the ability to meet demand in the domestic market.

In 3-digit SITC, there are 33 categories of chemical products. Among them, there are only 14 categories in which TCs are positive. The categories of products in which China has a comparative advantage are products that are little traded across the border, accounting for only 32.2 per cent of total trade volume. In the harmonised tariff system (HS), the same picture is revealed. Among 13 chapters in 2 sections, the TCs are positive for only 5 chapters, with a meagre 30 per cent of trade volume.

RCA is another type of index widely used to measure the competitiveness of an industry. It is generally accepted that when the RCA of an industry or product is equal to or larger than 2.5 , the industry or product is considered to be a strong comparative advantage industry; when the RCA is between 1.25 and 2.5 , the industry or product is fairly competitive; when the RCA lies between 0.8 and 1.25 , the industry or product is moderately competitive; and, when the RCA is lower than 0.8 , the industry or product has a comparative disadvantage. The RCA index gives a grim picture of China's chemical sector. Among 33 products items in the SITC, only 5 have RCA indexes above 2.5 , accounting for 15 per cent of the total. Nine items' RCA indicate fairly strong or moderate competitiveness. The lion's share of product items-58 per cent of the total-still fall in the comparative disadvantage group. Most of the products in China's chemical sector are under-represented in total exports, compared with China's competitors. 
THE COMPETITIVENESS OF CHINA'S CHEMICAL SECTOR

Table 9.1 Trade competitiveness index of the chemical sector (HS)

\begin{tabular}{|c|c|c|c|c|c|c|c|}
\hline & \multicolumn{3}{|c|}{$\begin{array}{c}1997 \\
\text { (US } \$ 10,000)\end{array}$} & \multicolumn{3}{|c|}{$\begin{array}{c}1992 \\
\text { (US } \$ 10,000)\end{array}$} & \multirow[t]{2}{*}{$\begin{array}{l}\text { 1992-97 } \\
\text { change }\end{array}$} \\
\hline & export & import & IC & export & import & IC & \\
\hline $\begin{array}{l}\text { Total chemical } \\
\text { Section VI }\end{array}$ & 1519013 & 2175891 & -0.1778 & 595187 & 1248445 & -0.3543 & 0.1766 \\
\hline Chemical or allied & 939162 & 1030228 & -0.0462 & 412289 & 717572 & -0.2702 & 0.2240 \\
\hline 28 inorganic & 238660 & 77452 & 0.5100 & 104953 & 37759 & 0.4708 & 391 \\
\hline 290 & 339636 & 306037 & 0.0520 & 140345 & 187557 & -0.14398 & 0.1960 \\
\hline 30 pharmaceutical & 63962 & 24352 & 0.4485 & 46011 & 31872 & 0.1815 & 0.2670 \\
\hline 31 fertiliser & 21192 & 299491 & -0.8678 & 2966 & 300370 & -0.9804 & 0.1126 \\
\hline $\begin{array}{l}32 \text { tan, dye, } \\
\text { pigments, etc. }\end{array}$ & 92215 & 104705 & -0.0634 & 35447 & 49978 & -0.1701 & 0.1067 \\
\hline 33 essential oil, etc. & 26644 & 7258 & 0.5718 & 18074 & 3299 & 0.6914 & -0.1195 \\
\hline 34 soap, agents, etc. & 22087 & 25769 & -0.0769 & 10229 & 16529 & -0.2354 & 0.1585 \\
\hline 35 albuminoidal, etc. & 7244 & 33499 & -0.6444 & 2325 & 13411 & -0.7045 & 0.0601 \\
\hline $\begin{array}{l}36 \text { explosive, } \\
\text { pyrotech }\end{array}$ & 23799 & 146 & 0.9878 & 15518 & 374 & 0.9529 & 0.0349 \\
\hline 37 photo & 13282 & 17145 & -0.1 & 3763 & 9116 & -0.4156 & 887 \\
\hline $\begin{array}{l}38 \text { miscellaneous } \\
\text { Section VII }\end{array}$ & 90442 & 134375 & -0.1954 & 32656 & 67307 & -0.3466 & 1512 \\
\hline Plastic & 579851 & 1145663 & -0.3279 & 182898 & 530873 & -0.4875 & 0.1596 \\
\hline 39 plastics \& article & 484389 & 1019882 & -0.3560 & 151642 & 475405 & -0.5163 & 0.1603 \\
\hline 40 rubber \& article & 95461 & 125781 & -0.1370 & 31257 & 55469 & -0.2792 & 0.1421 \\
\hline
\end{tabular}

Source: Customs Statistics, 1997, 1992; author's calculations.

International market share-gauged here by the percentage of one country's exports in total world exports-is another important indicator of industrial competitiveness. In 1996, the products of China's chemical sector constituted 2.1 per cent of the world market, much lower than the share of China's exports to the world total ( 3 per cent). Among 33 items, only 1 item's share exceeded 10 per cent; 5 items lay in the range of 5 to 10 per cent; 15 items were between 1 and 5 per cent; and 13 items were lower than 1 per cent.

\section{PRODUCT IDENTIFICATION}

The market performance of a product is jointly determined by its cost, price, quality and - more fundamentally - the productivity of its producer. Market competition, in most cases, takes the form of price competition among homogenous products. However, another form of competition-based on differential in function, quality and grade of product-is of increasing importance. These factors are examined in turn. 
APEC AND LIBERALISATION OF THE CHINESE ECONOMY

Table 9.2 Domestic to international price ratio for selected products

\begin{tabular}{lclc}
\hline Product & Price ratio & Product & Price ratio \\
methylbenzene & 1.15 & ethylene polymer & 1.24 \\
vinylbenzene & 1.42 & polystyrene & 1.01 \\
dimethylbenzene & 1.04 & PVC & 1.53 \\
methyl alcohol & 2.01 & propylene & 1.08 \\
glycol & 1.53 & ABS & 1.22
\end{tabular}

Notes: 1 . The price of international market is CIF in Far East Market. 2. The exchange rate for the renminbi $(\mathrm{RMB})$ is $U \mathrm{US} \$ 1=\mathrm{RMB} 8.29$.

Source: Calculation based on data from Price Weekly of Jihua Corporate.

Price. Price is a crucial factor in determining the competitiveness, and hence the market performance, of a product. However, the prices of chemical products in China are generally higher than those in the international market (Table 9.2). In some cases, the price of products is as much as twice the international market price. High prices have seriously weakened the competitiveness of China's chemical products.

Quality, variety and grade. Product differentials in terms of quality, variety and grade characterises high-level competition, such as that prevalent in the international market. Unfortunately, the quality, variety and grade differential between China and other countries is even greater than that in respect of price. Usually, the export to import price ratio is used to measure the quality differential between export and import goods. There is no question that the quality of most of China's exports is inferior to its imports (Table 9.3).

Table 9.3 Export to import price ratio for selected products, 1995

\begin{tabular}{lclc}
\hline & & & \\
Product & Price ratio & Product & Price ratio \\
\hline organic chemical & 3.62 & soap, agent, etc. & 0.69 \\
pharmaceutical & 0.40 & albuminoidal & 1.00 \\
fertiliser & 0.50 & explosive, pyrotechnic & 0.16 \\
tan, dye, pigment, etc. & 0.86 & photographic & 0.80 \\
essential oil, etc. & 0.59 & miscellaneous & 0.44
\end{tabular}

Source: Jin Pei et al., 1997. The International Competitiveness of China's Industry, Economic Management Press, Beijing. 
Limited variety and low grade of products are other important issues troubling China's chemical sector. Plastic is one example. In the United States, there are roughly 300-500 varieties of specifications in ethylene polymer and propylene polymer; in Japan, there are 793 varieties of high density ethylene polymer, 2450 in low density ethylene polymer, and 9169 in propylene polymer. But in China, China Petrochemical Corporation (Sinopec) - the main Chinese producer of plastic - only has 187 varieties and some firms produce only one or two varieties. There are more than 100,000 varieties of specialty chemicals, abroad; but China has only 18,000 . In the field of electronic chemicals, foreign producers produce more than 17,000 products; the same trade in China only produces 360 varieties. For consumption chemicals, Chinese enterprises have lost large market share because of the small number of varieties and low grade of products. The percentage of specialty chemical to total chemical products also demonstrates the general level of product grade. This figure is only 35 per cent in China-far below 60 per cent, the average level for developed countries.

\section{PRODUCTIVITY}

Labour productivity. Labour productivity is an important indicator of the efficiency of production factor utilisation. Strong competitiveness is necessarily linked with high factor efficiency. Labour productivity for the chemical sector as a whole in 1992 was 478,300 dollars per person per year in Japan, 274,000 dollars per person per year in the United States and 263,000 dollars per person per year in France. In China, the figure was only 619,000 yuan per person per year in 1995, less than one-thirtieth of that in developed countries.

Sinopec is among those enterprises with the highest labour productivity in China. However, when compared with its foreign competitors, Sinopec lags far behind. In 1996, Sinopec processed 118 million tonnes of crude oil, produced 2.45 million tonnes of ethylene; in the same year, Sinopec's workforce reached 665,000 . Labour productivity was 177.4 tonnes of crude oil per person per year, or 3.7 tonnes of ethylene per person per year. In 1995, the labour productivity of Exxon was 2250 tonnes of crude oil per person per year, or 41.3 tonnes of ethylene per person per year, 12.7 times and 11.2 times that of Sinopec, respectively. If labour productivity is measured by turnover per person, we find that while the workforce at Sinopec was the same size as that of the world's 7 largest companies, its turnover was less than one-third that of the world's tenthlargest company.

Installation productivity. Modern chemical industry depends heavily on large and complicated installations, so capacity and utilisation have become important factors determining enterprise efficiency. China's chemical sector, however, suffers from low capacity of installation and high consumption of raw materials 
due to low investment intensity and overlapping construction. In 1996, the average capacity of ethylene splitting installations in China was 226 kilotonnes per year, while the world average was 354 kilotonnes per year -1.6 times that of Chinaand the US average was 637 kilotonnes per year-2.8 times that of China. Since the beginning of the $1990 \mathrm{~s}, 7$ ethylene installations with capacity of less than 150 kilotonnes per year-with notable diseconomies of scale-have been built. This inherent inefficiency brought some of these projects to bankruptcy as soon as they began their operations.

The installation utilisation rate also plays a role in the determination of costs; this is especially true for huge production installations with heavy investment. The losses due to even short-term overhaul are considerable. Compared with foreign installations, China's installations need more frequent overhauls due to a low level of maintenance. The frequent overhauls not only lower the productivity of installations, but also increase the cost of examination and repairs.

Overall cost. The high cost of China's chemical sector products can be attributed to low installation, low labour productivity and poor management skills. High consumption of energy and materials is also a serious problem. For instance, although China's chemical sector has made substantial progress in energy savings-evidenced by the fact that the energy consumption for 10,000 yuan worth of output in 1995 was only half of that in 1990 (a reduction of 13.75 tonnes to 5.26 tonnes of standard coal), there is still a big gap between Chinese and foreign companies. China's energy consumption per unit of output is still as much as three times that of the United States, and nine times that of Japan. In 1996, Sinopec's energy consumption for producing one tonne of ethylene was 8.49 million kilocalories, much higher than the average level for a foreign company, 6-7 kilocalories. In high density ethylene polymer production, Sinopec has been left even further behind; its energy consumption per unit of output is almost twice that of foreign companies.

Cheap labour is the greatest advantage of China's industry. Labour cost in chemical production in China is lower than that of its foreign competitors. However, this only holds true for individuals, and not for the workforce as a whole. There are several reasons for this. First, the social burden of Chinese enterprises is very heavy. Enterprises are responsible for providing residency, medical insurance, pensions and even kindergarten education to their employees' families. Second, labour productivity is much lower than in a developed country, so the labour cost per unit of output is not as low as the low wages seem to indicate. Third, employees who are not engaged in production - such as auxiliary staff, logistics and administrative personnel-account for a much larger share of the workforce than their foreign competitors. All these factors conspire to create no advantage in labour cost in China's chemical industry. It is estimated that the ratio of labour cost to total cost in China's chemical industry just matches the foreign ratio. 
THE COMPETTTIVENESS OF CHINA'S CHEMICAL SECTOR

Table 9.4 Equipment status of large and medium-size chemical enterprises, 1995

\begin{tabular}{lrrrrrrr}
\hline Equipment & Total & $\begin{array}{c}\text { International } \\
\text { advances } \\
\text { Quantity }\end{array}$ & $\begin{array}{c}\text { Proportion } \\
\text { Puantity }\end{array}$ & $\begin{array}{c}\text { Domestic } \\
\text { advances }\end{array}$ & $\begin{array}{c}\text { Domestic } \\
\text { average }\end{array}$ \\
Ethylene & 20 & 6 & 30.00 & 6 & 30.00 & 4 & 20.00 \\
Quantity Proportion
\end{tabular}

\section{DEVELOPMENT CAPABILITY}

Equipment levels, R\&D input and the labour force of scientists and technicians are keys to fostering and sustaining the competitiveness of an enterprise. These factors indicate the potential of an enterprise to grow, and reflect its capability to attract investment and financing.

Equipment levels. Equipment is the physical base from which an enterprise can compete. In general, the quality, grade and cost of products are closely related to the equipment employed by an enterprise. The uncompetitiveness of China's chemical sector can partly be explained by the poor equipment in Chinese enterprises. Data from the Third National Industrial Census show that for large and medium enterprises in most chemical industries, internationally advanced equipment accounts for less than 20 per cent of the total (Table 9.4). The situation is worse in large enterprises. Furthermore, the most important and large equipment used in China's chemical sector is imported. This situation, coupled with weak innovation capacity and slow assimilation of imported technology, make it impossible for China to keep pace with world progress in equipment improvement.

$R \& D$ input. $R \& D$ is believed to be an essential element for an enterprise to establish and maintain its competitiveness in the market. The level of $R \& D$ is 
APEC AND LIBERALISATION OF THE CHINESE ECONOMY

Table 9.5 R\&D activities by large and medium enterprises, 1995

\begin{tabular}{|c|c|c|c|c|c|c|}
\hline Industry & $\begin{array}{c}\text { R\&D } \\
\text { expend. } \\
\text { (RMB } \\
10,000 \text { ) }\end{array}$ & $\begin{array}{c}\text { Scientists } \\
\& \\
\text { technicians }\end{array}$ & $\begin{array}{l}\text { Turnover } \\
\text { of new } \\
\text { product } \\
\text { (RMB } \\
10,000)\end{array}$ & $\begin{array}{c}\text { Turnover } \\
\text { (RMB } \\
(10 \\
\text { million) }\end{array}$ & $\begin{array}{c}\text { R\&D } \\
\text { input to } \\
\text { turnover } \\
(\%)\end{array}$ & $\begin{array}{l}\text { Turnover } \\
\text { of new } \\
\text { product to } \\
\text { total turnover } \\
(\%)\end{array}$ \\
\hline $\begin{array}{l}\text { raw materials } \\
\& \text { product }\end{array}$ & 82848.6 & 78586 & 1846271 & 2200 & 0.3792 & 8.45052 \\
\hline pharmaceutical & 48050.3 & 25059 & 615318 & 573 & 0.8385 & 10.7385 \\
\hline rubber & 23566.4 & 12248 & 355891 & 381.4 & 0.6178 & 9.33116 \\
\hline plastic & 8513.3 & 8372 & 328109 & 300.5 & 0.2833 & 10.9187 \\
\hline
\end{tabular}

indicative of both an enterprise's present and future potential. Again, there is a big gap between Chinese companies and world chemical giants. On average, large chemical enterprises in China spent less than 1 per cent of their turnover on R\&D activities, much less than 5 per cent, the rule of thumb for world chemical giants (Table 9.5). China's competitiveness can improve very little if this situation does not change.

Quantity and proportion of scientists and technicians. Scientists and technicians are the source of innovations. The quantity of scientists and technicians and their proportion of total staff are important indicators of innovative ability. Data shows that neither the quantity nor proportion of scientists and technicians in China's firms are less than in developed enterprises; some firms are even world leaders in this area. This is an important potential resource for China's chemical sector to tap.

\section{ENTERPRISE ENVIRONMENT}

\section{INDUSTRIAL CONCENTRATION}

Industrial concentration reflects the market structure, distribution of an industry, economies of scale and intensity of competition. Industrial concentration is thought to be a very important contributor to competitiveness in those industries where economies of scale or scope are notable. The chemical industry-especially the petrochemical industry-is one such industry. We use C4 and C8 (shares of the top 4 or 8 firms) to measure the concentration level of China's chemical sector (Table 9.6). The trends in the change in concentration ratios for different sub-sectors have differed. However, it is obvious that the concentration ratio of 
Table 9.6 Change in industrial concentration in China's chemical sector

\begin{tabular}{|c|c|c|c|c|}
\hline \multirow[t]{2}{*}{ Industry } & \multicolumn{2}{|c|}{1990} & \multicolumn{2}{|c|}{1994} \\
\hline & $\mathrm{C} 4$ & $\mathrm{C8}$ & $\mathrm{C} 4$ & $\mathrm{C} 8$ \\
\hline Raw materials \& product & 12.1 & 15.6 & 8.5 & 11.9 \\
\hline Daily use chemical & n.a. & n.a. & 10.6 & 15.8 \\
\hline Pharmaceutical & 6.5 & 9.7 & 7.7 & 13.2 \\
\hline Plastic & 4.5 & 6.1 & 1.9 & 3.2 \\
\hline
\end{tabular}

the chemical sector has not increased. This conclusion is also supported by the decreasing number and declining position of chemical firms in the 500 biggest companies listed. In 1991, there were 40 chemical companies in the top 500; by 1994, the number had decreased to 35 , and no chemical company appeared in the top 10. The ranking of chemical companies fell. In 1991, half the chemical companies in the top 500 ranked in the 300-500 range. In 1994, 63 per cent lay in this range.

These trends are the result of market reform. The removal of entry barriers has led to an influx of small and medium-sized enterprises into a highly concentrated industry. Industrial diffusion, on the one hand, intensifies domestic competition and in turn encourages firms to improve their competitiveness. However, it tends to reduce the efficiency of resource utilisation and is a difficult process in an open economy because the industry faces fierce competition from foreign chemical giants.

The petrochemical industry is characterised more notably by economies of scale than other chemical sub-sectors. We take examples such as ethylene, ethylene polymer, propylene, and styrene polymer to examine the concentration of China's petrochemical industry and cite the Japanese case as a reference (Table 9.7).

Table 9.7 Degree of concentration of selected products in China and Japan

\begin{tabular}{lcccc}
\hline Product & C4 & China & \multicolumn{3}{c}{ Japan } \\
& & C8 & C4 & C8 \\
\hline ethylene & 44.1 & 68.9 & 55.2 & 82.9 \\
polypropylene & 42.3 & 65.3 & 50.9 & 78.1 \\
polystyrene & 52.4 & 72.5 & 29.9 & 45.2 \\
ABS & 100 & 100 & 64.1 & 93.5 \\
Source: Information Institute of Jilin Petrochemical Co. & & \\
\end{tabular}


Table 9.8 Current and planned capacity of ethylene (kilotonnes)

\begin{tabular}{ccccccc}
\hline 1987 & 1990 & 1992 & 1995 & 1996 & 1997 & $\begin{array}{c}\text { Planned } \\
\text { capacity }\end{array}$ \\
\hline $\begin{array}{c}172.2 \\
195.0\end{array}$ & $\begin{array}{c}219.5 \\
\text { Source: China petrochemical economic information 1998.1. }\end{array}$ & & 359.0 & 412.0 & 823.5 \\
\hline
\end{tabular}

Compared with other developed countries, the extent of concentration in Japan is small. China's concentration level is even lower. This situation has already undermined the competitiveness of China's petrochemical industry.

Relation to upstream and downstream industry. The most important upstream inputs of the chemical sector in China-such as oil, coal, electricity and grainare natural monopolies. As is well known, when one industry is closely linked with another upstream or downstream industry, the market risk and transaction costs are higher than for an industry where this does not hold. The reason is that the monopoly buyer or seller may make use of its strong bargaining power to extract supernormal profit. To counteract this disadvantage, big chemical companies in developed countries are often vertically integrated so as to expand the boundary of the firm, reducing the market risk and transaction costs, and improving their competitiveness in the market.

In China, the chemical industrial chain is segmented. There are five big corporations. China Oil and Gas Corporation is responsible for extracting oil and gas, and China Xinxing Oil and Gas Corporation for prospecting resources. China Marine Oil Corporation is responsible for exploiting offshore oil fields. Sinopec was created to process the oil and gas and produce important chemical products, such as ethylene, propylene, synthetic resin, synthetic rubber, synthetic fibre and synthetic fertiliser. China National Chemical Import and Export Corporation almost has a monopoly on the international trade of chemicals. This configuration increases the risks and transaction costs of all these corporations, and weakens the competitiveness of China's chemical sector as a whole. If China is to open its market further, this situation must be changed.

Domestic demand. The scale and trend of demand also play a role in fostering the competitiveness of a firm. Situated in a big and rapidly growing market, a firm has more opportunities to mature as a big and strong producer. In this regard, China's chemical sector enjoys an exceptional advantage. The Chinese chemical market, fueled by China's rapid economic growth, will be expanding for a long period of time and is regarded as the world's largest potential markets. The Asia Pacific region has a strong concentration of both producers and consumers of 
chemical products. A booming market is emerging within reach of China's chemical sector. A good example is ethylene, one of the most important chemical products. It is estimated that the world's ethylene production capacity will be in surplus in 2000 while in Asia it will be in shortage. In China, even if all ethylene projects now under plan or construction can finish as scheduled, there is still a 20 per cent gap between supply and demand (Table 9.8). China's chemical sector stands to gain from this.

\section{THE COMPETITIVENESS OF CHINA'S CHEMICAL, SECTOR}

The immediate competitiveness of China's chemical sector-its market performance-is very poor, as indicated by various international trade competition indexes. This situation is to be expected given the inferior quality, high cost and price of China's chemical products. More fundamentally, weak competitiveness results from low productivity and low efficiency of resource utilisation, common phenomena among China's chemical sector. Although there are some favourable factors - such as a big and fast-growing market and a large number of scientists and technicians-substantial improvement in the competitiveness of China's chemical sector cannot be expected in the near future due to some unfavourable factors such as obsolete equipment, meagre $R \& D$ input, weak industrial organisation and lack of vertical integration between upstream and downstream industries. The low base from which the chemical sector began has, to date, prevented this sector from doing better. Subsequently, the competitiveness of China's chemical sector remains weaker than its foreign competitors. It has not yet matured sufficiently to participate in APEC's early sectoral liberalisation.

\section{THE IMPACT OF APEC EVSL ON CHINA'S CHEMICAL INDUSTRY}

The chemical sector in China is one of the most important sectors, evidenced by the fact that it is the second largest manufacturing sector. It accounts for over 10 per cent of total industry in terms of number of firms, output value, pre-tax profit, original value of fixed assets, and employees.

The competitiveness of China's chemical industry is still weak in comparison with its foreign competitors. China's participation in early chemical sectoral liberalisation will inevitably cause shocks to the domestic industry. The possible negative consequence include over-capacity of industry, deteriorating operation of enterprises, and increasing the number of unemployed. However, trade and investment liberalisation would increase the effective supply in the domestic market, help to introduce advanced equipment and technology, and upgrade the quality and grade of products as well as intensify domestic competition. All these will benefit the long-term development not only of the chemical sector, but the national economy as a whole. 
IMPORT SHOCKS

The immediate consequence of trade liberalisation would be to expose domestic enterprises to competition from foreign competitors in the domestic market. Given domestic enterprises' weak competitiveness, their market share will tend to decline. Since the beginning of the 1990s, China has reduced its tariff level by a significant margin. This has reduced the domestic market share of China's chemical sector by 4.6 percentage points, from 86.5 per cent in 1992 to 81.9 per cent in 1995.

Within the chemical sector, the impact on different sub-sectors varies. Here we use residual analysis to rank the impacts. The first assumption is that the production capacity utilisation level is determined by the interaction of supply and demand. The second assumption is that any deviation from average capacity utilisation is a result of import pressure on the domestic industry. The extent of the deviation reflects impact because all industries face similar non-import factors. We regress sales to production ratio $(\mathrm{Y})$ on production to demand ratio $(\mathrm{X})$. For each production to demand ratio, we calculate an expected sale to production ratio, then the residual between the actual and expected value. The smaller the residual for an industry, the more it suffers from import pressure (Table 9.9).

We find that the most affected industries are daily-use chemicals, plastics, special material chemicals, synthetic material and fertiliser. All these industries are mature industries both at home and abroad, for which the products are

Table 9.9 Estimation of the effect of imports on China's chemical sector

\begin{tabular}{llll}
\hline Industry & $\begin{array}{c}\text { Production } \\
\text { to sale }\end{array}$ & $\begin{array}{c}\text { Production } \\
\text { to demand }\end{array}$ & Residual \\
\hline daily use chemical & 89.77 & 98.00 & -3.3259 \\
plastic & 92.08 & 99.58 & -0.9958 \\
specialty chemical & 92.42 & 96.83 & -0.6905 \\
synthetic material & 93.72 & 53.86 & 0.0080 \\
fertiliser & 93.35 & 81.98 & 0.0303 \\
rubber & 93.36 & 98.44 & 0.2730 \\
pharmaceutical & 93.56 & 97.18 & 0.4501 \\
organic chemical & 94.00 & 98.42 & 0.9133 \\
pesticide & 94.23 & 98.19 & 1.1366 \\
basic material & 95.29 & 98.57 & 2.2009
\end{tabular}

Source: Calculations based on data from The Development Guide of China's Chemical Sector in 1997. 
highly substitutable. In this case, the advantage of foreign companies is maximised and domestic enterprises are driven into a corner. Other industries - such as the rubber industry, the pharmaceutical industry, organic chemicals, the pesticide industry and basic chemical material industry - are characterised by differentiated products, different target markets and stratified demand. In this case, increased imports do not necessarily increase direct competition from foreign countries. Hence, it can be seen that uncompetitive industries are not necessarily subject to import shocks.

We should not only take the present state of the market into account, but its dynamics as well. Ethylene is one example. By 2000 , the shortage of ethylene in China will reach 1500-2000 kilotonnes-equivalent to the output of five production installations. Consequently, an open market will not impact on domestic producers at all in the short term. However, ethylene production capacity in Asia is rapidly growing. If the market is opened now without good preparation, there will be fierce competition in the market in the near future.

\section{INVESTMENT LIBERALISATION SHOCKS}

Investment liberalisation means that two-way capital flows-both inflow and outflow - are free. However, in China, overseas investments made by domestic enterprises are very few. Here, we will only discuss the effect of foreign capital inflow.

In terms of the extent of foreign capital participation, the chemical sector is among the average of industries. The biggest sub-sector-the chemical raw material and chemical product industry - receives less foreign capital than other subsectors - such as the pharmaceutical, rubber and plastic industries (Table 9.10).

Free investment inflow is, in general, even harder to manage for the recipient country than free trade is, and this is especially true where the host is a developing

Table 9.10 Involvement of FDI in China's chemical sector

\begin{tabular}{lcc}
\hline Industry & $\begin{array}{c}\text { Invested assets } \\
\text { (RMB bil,) }\end{array}$ & $\begin{array}{c}\text { Proportion of FDI } \\
(\%)\end{array}$ \\
Raw material and product & 130.641 & 12.28 \\
Pharmaceutical & 33.346 & 14.55 \\
Rubber & 18.346 & 25.96 \\
Plastic & 45.946 & 30.08 \\
Total industry & 2155.288 & 14.37 \\
Source: Calculations based on data from China, Third National Industrial Census.
\end{tabular}


country. The first reason is that there is often a big gap in the scale, financing ability, technology, management level, market networking, product quality and grade, and brand name between China and foreign companies. Second, the multinational can mobilise resources globally to achieve its own global strategy. When its strategy conflicts with the interests of the host country, the host may suffer rather than benefit from capital inflow. Third, there are some institutional arrangements for developing countries in the World Trade Organisation (WTO) and other trade agreements to cushion the shock brought on by trade liberalisation, such as infant industries, exceptional articles and anti-dumping. However, how to manage investment inflows is still a hotly debated issue.

One important manifestation of foreign capital shocks is represented in the domestic market share of foreign funded enterprises (FFE). FFEs in the chemical sector already occupy considerable domestic market share (Table 9.11). Except in the chemical raw material and chemical product industries, the FFE market share for other sub-sectors is higher than the average for all industries. The market share of FFEs in the plastic industry is as much as 10 percentage points higher than the average. Among 40 industries, the plastic industry ranks $6^{\text {th }}$, the rubber industry $13^{\text {th }}$, and the pharmaceutical industry $16^{\text {th }}$, by FFE market share. In more detailed classifications, FFE market shares are even higher. For instance, the FFE market shares in synthetic rubber, daily use chemicals, bubble plastic and cosmetic products fall in the range of 30-40 per cent, soap and synthetic detergent above 40 per cent, and information chemicals above 50 per cent.

Foreign capital inflow also affects competition in the Chinese market. It intensifies domestic competition. However, it can also be destabilising. First, the introduction of foreign capital may bring about a monopoly. China does not have an established anti-trust legal system and is inexperienced in its implementation. Consequently, present institutional arrangements do not effectively prevent monopoly activities. Second, some FFEs infringe on publicly-

Table 9.11 Domestic market share of FFEs in China's chemical sector

\begin{tabular}{lcc}
\hline Industry & Market share (\%) & Rank within industry \\
\hline Raw materials and product & 11.86 & 22 \\
Pharmaceutical & 18.63 & 16 \\
Rubber & 21.19 & 13 \\
Plastic & 26.56 & 6 \\
Total industry & 16.93 & n.a. \\
Source: Wang Zhengzhong, 'On Issues of Present FFE in China', Reform, 1998.2.
\end{tabular}


accepted commercial morals and act uncompetitively towards their Chinese competitors, through big discounts, and worker abuse, for example.

\section{THE SHOCK TO THE NATIONAL ECONOMY}

The impacts of early chemical sectoral liberalisation are not confined solely to the chemical sector. Some negative effects on non-chemical sectors may be observed if the domestic chemical market is opened up too quickly. First, if foreign companies dominate the domestic chemical market, upstream industries such as crude oil will be placed in a very weak position. Because the price of domestic crude oil has been kept higher than the international price since 1997, domestic crude oil producers depend heavily on the domestic petrochemical industry. The monopoly of foreign chemical multinationals will further undermine the bargaining position of crude oil producers. Second, chemical products are important intermediate inputs for agriculture, light industry, textiles, building materials, machine building, electronics, automobiles, the military and hi-tech industries. The dominance of foreign chemical companies potentially damages the interests of these downstream industries. Third, the chemical sector accommodates more than 10 million workers in China. Employment concerns are a very important factor in deciding the timing and pace of early chemical sector liberalisation.

\section{POSITIVE EFFECTS OF TRADE AND INVESTMENT LIBERALISATION}

Opening the chemical market to a moderate extent will likely promote the development of related industries and cause minimal harm to the domestic industry. There are several reasons for this.

The domestic chemical sector cannot satisfy domestic demand for chemical products. The importance of the chemical sector means that its development influences the development of downstream industries and the national economy as a whole. According to the 1990 China input-output table, the responsive index of the chemical sector is highest in all sectors, reaching 2.7989. This indicates that the development of non-chemical sectors depends heavily on chemical products. If the supply of chemical products does not meet domestic demand, the development of non-chemical sectors is compromised. The data from Table 9.9 indicates that production of chemical products in high demand is still insufficient. Not surprisingly, the largest trade deficit occurred in those product categories. Therefore, in this case, further opening of the market through lowering tariffs will not introduce direct competition to the domestic industry; it will help reduce the import costs of downstream industries of the chemical sector and in turn strengthen the competitiveness of these industries. There is still much room for domestic enterprises to grow in China's huge market, even 
with an increasingly open environment. It is estimated that domestic demand growth in industries where there are shortages will be sustained for a considerable length of time and that domestic supply will not keep pace with demand due to deficient investment. Opening the market and foreign capital inflow will fill this gap and ease the constraints imposed by these industries on China's economic development.

Even in those industries where production basically satisfies demand, opening the market will not necessarily damage domestic industries. One reason is increasing market stratification, meaning that consumers can no longer be seen as homogeneous. This makes it possible for both domestic and foreign producers to find a niche and target clients in the market. Trade in differentiated products is becoming increasingly prevalent, thus leaving room for domestic enterprises to develop.

The endurance of domestic industries has been strengthened following big tariff reductions. Since 1994, China's tariffs have fallen dramatically. The arithmetic average tariff for chemical products is only 11 per cent-much lower than the overall arithmetic average tariff of 17 per cent. Contrary to expectations, domestic enterprises did not experience strong competition from imports. One possible explanation is that applied tariffs were already very low, so that nominal tariff cuts had little influence on tariffs actually applied. Indeed, in 1997, tariffs on many chemical products were levied at only one-half or one-third of the base tariff. Preferential tariffs for some products are even one-tenth of base tariffs. In addition, smuggling is a serious problem in China. Illegally trafficked goods account for considerable market share and are totally tax free. Consequently, applied tariffs in China are much lower than nominal tariffs. This has two implications. One is that China's chemical sector is not a heavily protected sector as nominal tariffs seem to indicate. The other is that it is still a great challenge to lower the nominal tariff level without sacrificing protection.

It is a good time to attract foreign direct investment (FDI) in the chemical sector. The industries of chemical raw materials and chemical products-the main body of China's chemical sector-receive little FDI, compared with the national industrial average. There is much potential to expand FDI. The international chemical sector is preparing for a new round of restructuring. The chemical multinationals in developed countries are beginning to shift their business to specialty chemicals and the life science industry while transferring their bulky chemicalsmostly raw or primary chemical products characterised by large-scale and huge installation - to developing countries. For instance, the petrochemical industry is growing strongly in the Asia Pacific region. It is estimated that ethylene production in Asia will double within 15 years. This represents a good opportunity for China to develop its chemical sector. The moderate degree participation of APEC's early sector liberalisation will help China attract more FDI. Given that China's 
neighbouring countries and regions are competing strongly in this field, China must make every effort to grasp this historic opportunity.

\section{POLICY AND MEASURES FOR CHINA'S PARTICIPATION IN APEC EVSL}

Given that the benefits and losses arising from EVSL are unevenly distributed among APEC members, the current arrangements of EVSL-in terms of both timing and product coverage - seem unacceptable for those members with weak international competitiveness. Some mechanism should be put in place to balance the gains and losses from EVSL among APEC member economies. However, such a mechanism is not forseeable in the short term. A practical way to deal with the issue is to leave timing and product coverage determination to member economies, so they can balance the benefits and losses internally.

A phased, selective liberalisation process is the best way for China to reap the benefits (and minimise the costs) of liberalisation. China should keep its options open to participate fully in early sectoral liberalisation when the timing is appropriate. The pace of domestic restructuring should be quickened to promote the competitiveness of the chemical sector, China's key to participating in early sectoral liberalisation.

\section{THE MEASURES FOR TRADE LIBERALISATION}

Although at present it cannot endure the shock from full participation in APEC EVSL, China should continue the trade liberalisation process according to its Individual Action Plan. Trade policy measures - both tariff and non-tariffshould achieve a dual purpose: satisfying domestic demand and improving the competitiveness of China's chemical sector.

Tariff concessions. To fulfil China's commitment to APEC trade liberalisation and WTO accession, China should further lower its chemical products tariff, especially the nominal tariff, which is still among the highest in the world. Further tariff concessions also pave the way for China to join APEC EVSL in the future. Tariff cuts should be based on the following principles

- lowering the general chemical products tariff. The effect of earlier tariff cuts indicates that China's chemical sector can bear further tariff cuts. As the value-added tax for imported goods is still high, it can counteract the negative effects of tariff cuts. To illustrate China's determination to catch up with APEC early sector liberalisation, it should declare another round of tariff reductions on chemical products when APEC formally launches its EVSL process. Making large cuts to the base tariff-which is much higher than the applied tariff-would be advisable. 
- timing the adjustment of the tariff level to match changes in products' competitiveness. This will create a favourable environment for products well-placed to enter the international market.

- adopting a differentiated tariff regime based on the relative importance of products. It is not necessary for China to provide protection for all internationally uncompetitive chemical products. For those products with strategic significance in China's national economy, the exceptional articles in the WTO agreement for imposing protective tariffs can be cited. Protection should be neither too long nor too excessive. For those products less important to the national economy, demand can be met through international labour division. The tariff on these products can be used as bargaining counters in tariff negotiations.

Adjustment in tariff structure. China applies ad valorem tariffs to almost all imported goods. To adapt to an open economy, a more flexible tariff structure should be established. Such a structure should

- apply specific tariffs or compound tariffs to selected products

- apply a sliding-scale duty to those products whose price fluctuations are very large in the international market, so as to achieve a relatively stable price in the domestic market

- apply quotas tariff to selected products, within quotas, a low tariff is applied

- establish emergency tariff regulations, including temporary protective tariffs.

Non-tariff measures. China has committed to reduce its non-tariff trade barriers. Dismantling non-tariff barriers was an important part of its earlier tariff cuts package. China will continue its efforts. Gradually, China will abolish quota controls, import licensing and other trade control measures. In line with international practice, China should establish its own competition policy to promote fair competition in the domestic market and import standards to protect consumer rights. It should also

- refine China's anti-dumping laws to promote fair competition in the domestic market

- tighten environmental and sanitary standards on imported goods. Chemical products are environmentally and health sensitive. The production, transportation, storage and consumption of chemical products can have disastrous environmental and health consequences. As a precautionary measure, China should impose stricter standards in this regard.

\section{INVESTMENT LIBERALISATION}

China should be more prudent about investment liberalisation. It should proceed in a planned and phased manner. China needs to promote investment liberalisation in the following ways 
- continue to promote investment facilitation. Open and transparent laws and regulations regarding foreign investment are the first step to promoting investment facilitation. China has advanced a lot in this regard. A notable event is the promulgation and revision of the 'Provisions on Guiding Foreign Investment Direction Catalogue For The Guidance Of Foreign Investment Industries by the State Development Planning Commission'.

- implement investment liberalisation in a phased and product-specific manner. China has committed itself to achieving investment liberalisation by 2020 . If the chemical sector eventually participates in the APEC EVSL process, the deadline for chemical products will be brought forward. Hence, it is important to set out some kind of timeline for liberalisation. Similarly, the products to undergo liberalisation must be specified.

- coordinate investment and trade liberalisation. Priority products in trade liberalisation should also be priority products in investment liberalisation.

- adjust foreign investment policy in a timely manner. The policy stance on FDI is still that it needs to be stepped up. But it must be kept in mind that a level playing field for competition is the ultimate policy target. Special attention to foreign direct investment (FDI) should only be limited to products that are crucial to promoting economic development and improving the competitiveness of China's enterprises.

\section{DOMESTIC RESTRUCTURING POLICY}

The key to improving the competitiveness of China's chemical sector is restructuring the sector domestically. Adjustments need to be made in ownership, industrial organisation and product structure. There is also a role for government to create a favourable environment for the development of chemical enterprises. The following measures should be adopted

- speed up state-owned enterprise (SOE) reform. SOEs are the main body of China's chemical sector. Without vigorous and active SOEs, China cannot establish a competitive advantage in the international market. The targets of SOE reform are to establish a modern enterprise system characterised by clearly defined property rights, the demarcation of enterprises and administration, and own responsibility for profits, losses and scientific management. Property rights reform should be prioritised so as to improve the SOE incentive mechanism.

- diversify ownership within the chemical sector. Since reforms began, the entry of the non-state sector has injected vigour into the chemical sector. The non-state sector is expected to play an increasingly active role in international competition.

- reorganise the industrial organisation of the chemical sector according to its technical characteristics. Efforts should be made to promote vertical 
integration of the petrochemical industry, through such measures as mergers, acquisitions and the introduction of a shareholding system. Longstanding troubles-such as overlapping construction and undersized enterprises-should be tackled as soon as possible.

- adjust industrial and product structure. Poor industrial and product structure are significant contributors to the weak competitiveness of China's chemical sector. The proportion of petrochemical and specialty chemicals - both high value-added products-is too low. The chemicals of these two industries should be prioritised in chemical industry development.

- speed up technological progress and innovation in the chemical industry. The chemical sector is a technology-intensive industry, so competition in science and technology is the focus of chemical industry competition. The first step is to increase $R \& D$ input, and promote cooperation among industry, research and academic circles. Another important aspect is to introduce advanced technology and equipment from foreign countries. A supportive policy should be established to encourage this.

- encourage chemical enterprises to actively participate in international competition. The government should raise tax rebates, increase export credit and reduce the interest rate. Overseas investment by chemical enterprises should also be encouraged.

It is important for the government to create favourable environment for chemical sector development. Besides providing supportive policies and an effective legal system, the government should attempt to prevent rampant smuggling, from which many of China's enterprises suffer greatly. 